\title{
Carbamazepine and Multiple Myeloma: Possible Interaction
}

\section{Karbamazepin ve Multipl Miyelom: Olası İlişki}

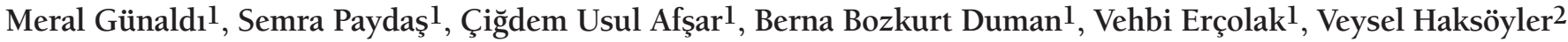 \\ ${ }^{1}$ Çukurova University Faculty of Medicine, Department of Medical Oncology, Adana, Turkey \\ ${ }^{2}$ Çukurova University Faculty of Medicine, Department of Internal Medicine, Adana, Turkey
}

\section{To the Editor,}

Epilepsy is the most common chronic neurological disease and patients are treated by various classes of antiepileptic drugs [1]. In addition to their acute side effects, there are long-term adverse effects of antiepileptic drugs [2]. Hemopoietic neoplasias such as lymphoma, multiple myeloma, and some solid cancers including lung, liver, pancreas, and gastrointestinal cancers are the malignant disorders most frequently discussed in relation to use of antiepileptic drugs $[3,4]$. The carcinogenic effect of carbamazepine is very limited. However, there are some case reports and series containing a limited number of cases of hypogammaglobulinemia, monoclonal gammopathy of undetermined significance (MGUS), and multiple myeloma $[3,4,5,6,7,8,9,10,11]$. We present here a 54 year-old woman with multiple myeloma with long exposure to carbamazepine. Vertebral fracture was detected and vertebroplasty was done urgently. There was no evidence of neurologic deficit. She had a history of $400 \mathrm{mg}$ carbamazepine usage for more than 20 years due to idiopathic epilepsy. Laboratory examination showed total protein/albumin of $8.85 / 3.41 \mathrm{~g} / \mathrm{dL}$ and calcium of 10.77 $\mathrm{mg} / \mathrm{dL}$ (8.4-9.2); she had macrocytic anemia. Bence-Jones protein in the urine was not demonstrated. Protein electrophoresis showed an M-peak (Figure 1) with an elevated serum level of immunoglobulin G (IgG) of $2740 \mathrm{mg} / \mathrm{dL}$. Immunoelectrophoresis revealed M-protein composed with a kappa chain. Bone marrow aspiration and biopsy showed 90\% plasma cell infiltration and CD38 and kappa were positive. Cytogenetic analysis of bone marrow showed $17 \mathrm{p}$ deletion $(+), 13 \mathrm{q}$ deletion $(+), \mathrm{t}(11 ; 14), \mathrm{t}$ $(4 ; 14)$. Histopathological examination of a vertebroplasty specimen revealed plasma infiltration. Carbamazepine usage was stopped and treatment was continued with valproic acid. A regimen containing bortezomib $\left(1.3 \mathrm{~g} / \mathrm{m}^{2}\right)$, dexamethasone $(40 \mathrm{mg})$, and zoledronic acid was prescribed. After 4 courses of chemotherapy, blood and bone marrow exams were normal. Stem cell transplantation was planned for consolidation. Carbamazepine-related multiple myeloma has been reported in a few case reports. It has been suggested that carbamazepine may cause the IgG type of M-protein multiple myeloma, MGUS, and hypogammaglobulinemia

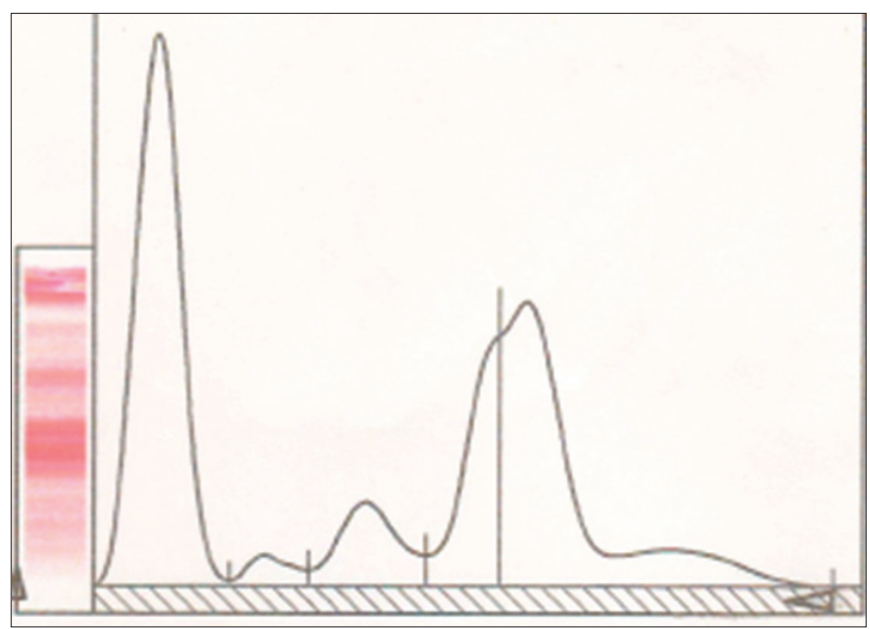

Figure 1: Abnormal serum protein electrophoresis pattern in a patient with multiple myeloma. Note the large spike in the early gamma region. 
$[5,6,9,11,12]$. Our patient was younger than is usual for multiple myeloma. We can speculate that the exposure to an extrinsic factor may be associated with younger age in this case. The relationships among the duration of use of antiepileptic drugs, cumulative dose of antiepileptic drugs, and development of multiple myeloma are not known completely. In our case, multiple myeloma developed after 20 years of carbamazepine use. In conclusion, carbamazepine may be a potential drug in the development of multiple myeloma. For this reason, periodical evaluation of serum levels of immunoglobulin is necessary in patients receiving carbamazepine.

Key Words: Multiple myeloma, Carbamazepine, Epilepsy.

\section{Conflict of Interest Statement}

The authors of this paper have no conflicts of interest, including specific financial interests, relationships, and/ or affiliations relevant to the subject matter or materials included.

\section{References}

1. Bell GS, Sander JW. The epidemiology of epilepsy: the size of the problem. Seizure 2001;10:306-314.

2. White SJ, McLean AEM, Howland C. Anticonvulsant drugs and cancer: a cohort study in patients with severe epilepsy. Lancet 1979;2:458-461.

3. Sander JW. The epidemiology of epilepsy revised. Curr Opin Neurol 2003;16:165-170.

4. Olsen JH, Schulgen G, Boice JD Jr, Whysner J, Travis LB, Williams GM, Johnson FB, McGee JO. Antiepileptic treatment and risk for hepatobiliary cancer and malignant lymphoma. Cancer Res 1995;55:294-297.
5. Tohen M, Castillo J, Baldessarini RJ, Zarate C Jr, Kando JC. Blood dyscrasias with carbamazepine and valproate: a pharmacoepidemiological study of 2,228 patients at risk. Am J Psychiatry 1995;152:413-418.

6. Kyle RA, Rajkumar SV. Monoclonal gammopathies of undetermined significance. Hematol Oncol Clin North Am 1999;13:1181-1202.

7. Matzner Y, Polliack A. Monoclonal gammopathy and subsequent multiple myeloma in a patient on chronic diphenylhydantoin therapy. Isr J Med Sci 1978;14:1265-1267.

8. Voutsinas D, Foudoulaki L, Sofroniadou K, Galanakis N. Visceral leishmaniasis in a patient with acquired hypogammaglobulinemia. Eur J Intern Med 2001;12:127-129.

9. Selby JV, Friedman GD, Fireman BH. Screening prescription drugs for possible carcinogenicity: eleven to fifteen years of follow up. Cancer Res 1989;49:5736-5747.

10. Kanoh T, Dobashi H, Inada T. Multiple myeloma associated with phenytoin (diphenylhydantoin) therapy. Rinsho Ketsueki 1996;37:239-243.

11. Moreno-Ancillo A, Cosmes Martín PM, Domínguez-Noche C, Martín-Núñez G, Fernández-Galán MA, López-López R, González-Hurtado JA, Gil-Adrados AC. Carbamazepine induced transient monoclonal gammopathy and immunodeficiency. Allergol Immunopathol (Madr) 2004;32:86-88.

12. Adelöw C, Ahlbom A, Feychting M, Johnsson F, Schwartzbaum J, Tomson T. Epilepsy as a risk factor for cancer. J Neurol Neurosurg Psychiatry 2006;77:784-786. 